\title{
Persoonallista ja perinteistä - Erik Lindströmin iskelmien melodiamotiivit
}

Teen parhaillani Erik Lindströmin (s. 1922) musiikillista uraa ja sävellystuotantoa käsittelevää tutkimusta, joka on luonteeltaan tekijälähtöinen. En siis pyri esimerkiksi selvittämään Lindströmin sävellysten reseptiota, vaan tutkimusaineiston muodostavat itse sävellykset (äänitteet ja nuotit), Lindströmiä käsittelevä aikaisempi haastattelu- ja kirjallinen materiaali sekä itse tekemäni haastattelut.

Tutkimukseni on pääpiirteissään samantapainen kuin yhdessä Risto Kukkosen kanssa kirjoitettu monografia Toivo Kärjen musiikillinen tyyli (Henriksson \& Kukkonen 2001). Tärkeimpänä erona on se, että tällä kertaa pyrin kartoittamaan Lindströmin sävellystuotannon lisäksi perusteellisemmin myös hänen musiikillisen uransa vaiheita, sillä hänestä ei ole toistaiseksi ilmestynyt elämäkertaa.

Erik Lindströmillä on takanaan poikkeuksellisen pitkä ura muusikkona, säveltäjänä, orkesterinjohtajana ja tuottajana. Hän soitti ensimmäisen keikkansa jo 1930-luvulla, ja 2000-luvulla hän säveltää ja soittaa edelleen aktiivisesti. Lindström on intohimoinen jazzmuusikko, mutta ammattitaitoisena ja paljon käytettynä studiomuusikkona hän on soittanut pitkän uransa aikana kevyttä musiikkia laidasta laitaan.

Lindström on säveltänyt noin 500 iskelmää tai jazzkappaletta ja lukuisia viihdeorkesteri- ja big band -teoksia. Tähän mennessä olen keskittynyt Lindströmin iskelmien analysoimiseen, sillä ne muodostavat määrällisesti selvän enemmistön hänen sävellystuotannostaan. Olen valinnut tarkemman analyysin kohteeksi 74 iskelmää. Ensisijaisen tutkimusaineiston muodostavat äänitteet ja painetut nuotit. Niiden joukossa ovat Lindströmin suurimmat kaupalliset menestykset, mutta aineistossa on myös Lindströmin (2002) omia suosikkisävelmiä, jotka eivät syystä tai toisesta ole nousseet myyntilistojen kärkeen.

Olen käyttänyt sävellysten tyyli-ja sävellajeja tutkiessani laajempaa 171 sävelmän otosta, jossa on edellä mainittujen 74 sävelmän lisäksi 97 muuta satunnaisesti valittua Lindströmin sävellystä. Tätä laajempaa 171 sävelmän aineistoa nimitän tässä artikke- 
lissa "vertailuaineistoksi" ja 74 sävelmän varsinaista aineistoa "tutkimusaineistoksi". Aineistoon kuuluvat sävelmät on lueteltu artikkelin lopussa.

Analyysimenetelmät ovat pitkälti samat kuin aikaisemmassa Toivo Kärki -tutkimuksessa (Henriksson \& Kukkonen 2001). Melodia-analyysissa olen käyttänyt Risto Kukkosen Toivo Kärjen iskelmien melodioihin soveltamaa ns. paradigmaattista menetelmää (Kukkonen 2001; Henriksson \& Kukkonen 2001: 100-112). Menetelmän takana ovat lähinnä Nattiezin (1982), Pekkilän (1988) ja Kuljuntaustan (1994) esittelemät metodit. Kukkosen metodissa paradigmaattinen analyysi ei kuitenkaan perustu nuottien visuaaliseen hahmoon, kuten yleensä, vaan niiden synnyttämään soivaan mielikuvaan. Käytännössä tämä tarkoittaa melodioiden käymistä läpi säveltapailun avulla. Tässä tutkimuksessa olen soveltanut paradigmaattista menetelmää melodian lisäksi myös keskeisten rytmimotiivien tutkimiseen.

Harmonia-analyysissa olen käyttänyt itse kehittämääni saksalaisen funktioteorian muunnosta, joka pohjautuu erityisesti Diether de la Motten teorioihin (ks. Henriksson 1998; Motte 1976). Rakenneanalyysi puolestaan perustuu populaarimusiikin rakenteiden luokitteluun, jossa rakenteet jaetaan säkeistömuotoihin, verse/chorus-muotoihin sekä säkeistö/kertosäkeistö-muotoihin (ks. Henriksson \& Kukkonen 2001: 175181; Nurmesjärvi 2000).

Keskityn seuraavassa pääasiassa Erik Lindströmin käyttämiin melodiamotiiveihin. Koska Lindströmin sävellyksissä melodia liittyy kuitenkin aina kiinteästi muihin musiikillisiin elementteihin - esimerkiksi muotoon ja harmoniaan - käsittelen ensin lyhyesti Lindströmin sävellystyylin keskeisiä piirteitä.

\section{Säveltäjä Erik Lindström}

Lindströmin ensimmäinen levytetty sävelmä oli Armi vuodelta 1952. Valtaisa menestys oli Annikki Tähden laulama Muistatko Monrepos'n (1955), josta tuli Suomen ensimmäinen kultalevy. Muita 50-luvun hittejä olivat esimerkiksi Helena Siltalan laulamat Pikku midinetti, joka oli peräti 14 viikkoa Yleisradion listaykkösenä, Ranskalaiset korot, Tuuli tuo, tuuli vie ja Etkö uskalla mua rakastaa.

Vuonna 1964 Lindström perusti yhdessä Rolf Kronqvistin kanssa Finndisc-levyyhtiön, joka toimi vuoteen 1971 saakka. Yhtiö löysi mm. Juha Vainion, Martti Innasen ja Irwin Goodmanin. Lindströmin talliin kuului myös ratalankayhtye Adventures. Innaselle ja Vainiolle Lindström sävelsi nimimerkillä "P. Naseva" humoristisia lauluja. Innanen esitti esimerkiksi tangoparodiat Elsa, kohtalon lapsi ja Esteri, tyttö sadepisarain. Vainio puolestaan lauloi useita Janatuis-sävelmiä, jotka nauroivat itseironisesti jazzmuusikoille.

Lindström vietti 1970-luvulla talvikaudet useimmiten Floridassa. Amerikan maisemat eivät inspiroineet uusiin sävellyksiin, mutta palattuaan Suomeen hänen sävel- 
kynänsä alkoi jälleen toimia. Sävellyksiä onkin syntynyt aina näihin päiviin saakka. Esimerkiksi yhteistyö laulaja Pirjo Kämpin kanssa on tuottanut radiosoittomenestyksiä.

Lindström on tehnyt yhteistyötä useiden eri sanoittajien kanssa. Erityisen läheinen yhteistyösuhde hänellä on vaimonsa Vuokon kanssa, joka on keksinyt aihepiirin moneen Lindströmin sävelmään. Muita keskeisiä sanoittajia ovat olleet muun muassa Sauvo Puhtila eli Saukki, Juha Vainio, Martti Innanen ja Aappo I. Piippo.

Erik Lindströmin (2002) mukaan hänen sävellystensä alkuideat tulevat spontaanisti. Tämän jälkeen hän työstää melodia-aiheita eteenpäin, kunnes sävellys on valmis. Valmiita sävellyksiä analysoitaessa näyttäisi siltä, että sekvenssitoisto on erittäin keskeisessä asemassa Lindströmin työstäessä alkuideaansa.

Hyvin usein koko sävellys perustuu tiettyyn muutaman tahdin mittaiseen rytmiaiheeseen, jota toistetaan. Rytmiaiheiden toisto helpottaa suuresti sanoittajan tehtävää. Samalla sävelmien rakenteet hahmottuvat paremmin kuulijalle. Rytmimotiivien toisto onkin iskelmämusiikille hyvin tyypillinen ilmiö. Antti Karhumäen (1999: 38-44) tutkimuksen mukaan - jossa oli analysoitu 83 suomalaisen huippuhitin otos - peräti 99 \% sävelmistä esiintyi rytmiaiheiden toistoa, ja kaikkiaan $23 \%$ sävelmistä perustui ainoastaan yhden rytmimotiivin toistoon.

Samalla kun Lindström toistaa tiettyä rytmiaihetta, saattaa myös melodia säilyä samana. Useimmiten melodiaa ei kuitenkaan toisteta mekaanisesti eri sävelkorkeuksilta, vaan hieman muunneltuna siten, että yksittäiset sävelet sopivat paremmin säestysharmoniaan. Hyvä esimerkki on Kielletty rakkaus, jossa pienten melodian muutosten ansiosta syntyy tehokkaita pidätyssäveliä suhteessa säestykseen (nuottiesimerkki $1)$.

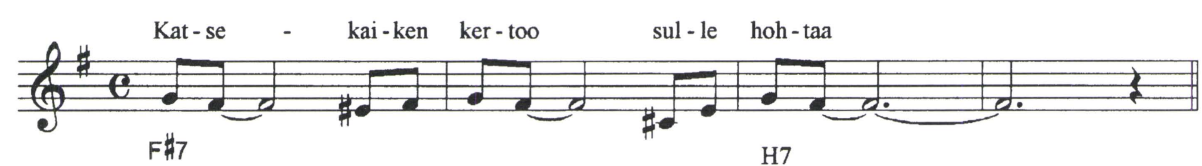

H7

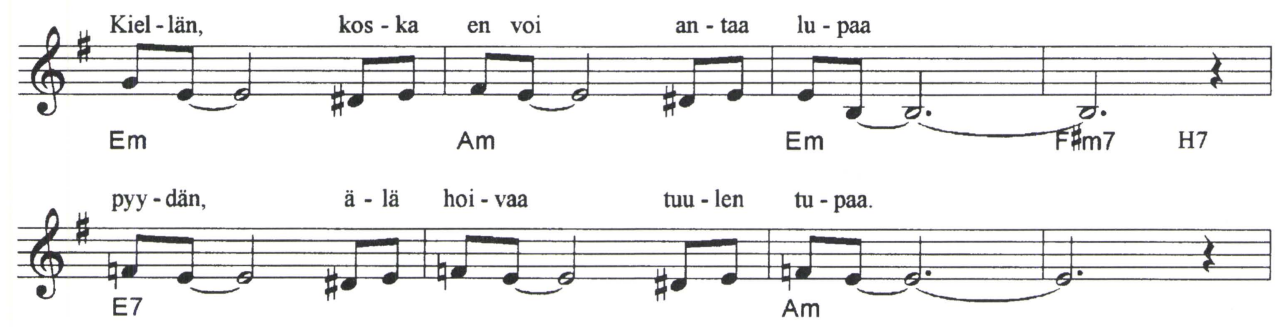

NUOTTIESIMERKKI 1. Kielletty rakkaus, tahdit 13-24.

Erik Lindström (2002) pitää omien sanojensa mukaan enemmän duurista kuin mollista. Siitä huolimatta vertailuaineiston sävelmistä noin $2 / 3$ on sävelletty molliin. Lind- 
ström on ilmeisesti yrittänyt vastata suomalaisten kysyntään säveltämällä mollitangoja, -valsseja ja -humppia. Molli-iskelmähän on suomalaisten suosiossa, sillä esimerkiksi Antti Karhumäen (1999: 45) tutkimuksen mukaan peräti $86 \%$ suomalaisista huippuhiteistä on mollissa. Lindströmin tuotannossa duurisävelmiä on siis jonkin verran enemmän kuin suomalaisessa iskelmässä keskimäärin.

Tyylilajeista Lindströmin (2002) omia suosikkeja ovat hitaat amerikkalaisvaikutteiset duurifoksit sekä erilaiset latinalaisrytmit. Vertailuaineiston sävelmistä reilut $10 \%$ on "lattareita" ja lähes $20 \%$ duurifokseja. "Lattareista" hänen suosiossaan on erityisesti beguine, mutta hän on säveltänyt myös muun muassa samboja, bossa novia, calypsoja ja boleroita. Lindström on säveltänyt selvästi keskimääräistä suomalaista iskelmäsäveltäjää enemmän fokseja ja latinalaisrytmejä, sillä esimerkiksi Karhumäen (1999: 64) mukaan yhteensä 83 kotimaisesta huippuhitistä vain $7 \%$ oli fokseja ja 3,5\% beguineja.

Lindströmin (2002) musiikilliset juuret ovat hänen omien sanojensa mukaan amerikkalaisessa populaarimusiikissa ja swing-tyylisessä jazzissa. Tämä näkyy esimerkiksi sävellysten rakenteissa, jotka perustuvat suurelta osin amerikkalaisen populaarisävelmän verse/chorus-muotoon. Tosin suurimmassa osassa sävelmistä on vain chorus-osa. Verse ei nimittäin enää ollut muodissa 1950-luvulla, jolloin Lindström aloitti iskelmäsävellysuransa. Esimerkiksi Toivo Kärki alkoi tässä vaiheessa jättää monista tangoistaan versen pois (Henriksson \& Kukkonen 2001: 68).

Lindströmin erityisessä suosiossa tuntuu olevan 32 tahdin AABA-muoto, sillä yli neljännes tutkimusaineiston sävelmistä perustuu tähän rakenteeseen. Tämän lisäksi aineistossa on runsaasti erilaisia AABA-muodon muunnoksia ja laajennuksia (esimerkiksi AABAA ja AABABA). Kaikkiaan lähes puolet sävelmistä pohjautuu joko AABA-muotoon tai sen muunnoksiin. Seuraavaksi yleisin chorus-osan muoto on $\mathrm{ABAB}$, joita on tutkimusaineistossa noin $15 \%$.

Verse/chorus-rakenteen lisäksi Lindström on käyttänyt 1960-luvulta lähtien popmusiikista tuttua säkeistö/kertosäkeistö-muotoa, joka on yleisin muotorakenne hänen uudemmassa tuotannossaan. Säkeistö/kertosäkeistö-muotoa esiintyy kaikkiaan noin $25 \%$ tutkimusaineiston sävelmistä. Näistä lähes puolet perustuu yksinkertaiseen rakenteeseen, jossa sekä 16 tahdin säkeistö että samanpituinen kertosäkeistö muodostuvat toistuvista 8 tahdin aiheista.

\section{Harmonia}

Lindströmin sävelmissä melodia ja harmonia muodostavat aina yhtenäisen kokonaisuuden. Tässä suhteessa hän muistuttaa Toivo Kärkeä (Henriksson \& Kukkonen 2001: 100). Tämä onkin ymmärrettävää, sillä molemmat ovat saaneet vaikutteita jazzista. Toivo Kärjen tapaan myös Lindströmillä sointuja laajentavat melodian pidätyssävelet 
ovat erittäin tärkeässä asemassa. Hän käyttää pidätyksiä sekä melodiafraasien alussa että niiden lopussa - aivan kuten Kärkikin (Henriksson \& Kukkonen 2001: 133-134).

Lindströmin soinnutuksessa on jonkin verran enemmän kromaattisia muunnesäveliä kuin esimerkiksi Toivo Kärjen soinnuissa. Lindström saattaa muun muassa lisätä dominanttisointuun (V tai V7) ylinousevan kvintin (C-duurissa sointu G+ tai G7+5) tai pienen noonin (G7b9). Huomionarvoista on, että Lindström saattaa käyttää jälkimmäistä sointua mollin lisäksi myös duurissa.

Lindströmillä tuntuu olevan muutamia suosikkisointuja, jotka hän sijoittaa sävelmän melodiseen ja/tai sanoitukselliseen huippukohtaan. Näistä ehkä persoonallisin on luonnollisen mollin VI asteen sointu, jota on käytetty esimerkiksi kappaleissa Ranskalaiset korot sekä Muistatko Monrepos 'n. Jälkimmäisessä (nuottiesimerkki 2) bVI7soinnun yhteydessä on erittäin tehokas noonipidätys, jota voidaan pitää sävellyksen tärkeimpänä melodis-harmonisena koukkuna. Kappaleessa Yön värit samaa sointua on käytetty duurissa, jolloin sen teho on vieläkin suurempi. Toisinaan Lindström käyttää duurissa myös I asteen vähennettyä sointua kappaleen huippukohdassa. Tämä sointu voidaan tulkita bVI7-soinnun vajaamuodoksi, josta on jätetty pohjasävel pois (esimerkiksi C-duurissa sointu Cdim voidaan tulkita soinnun Ab7 vajaamuodoksi).

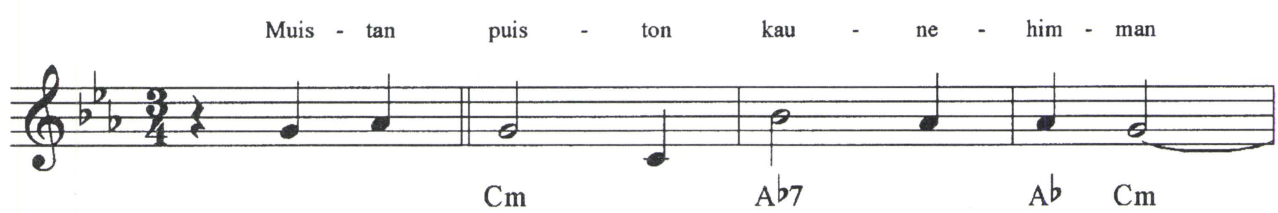

NUOTTIESIMERKKI 2. Muistatko Monrepos'n, tahdit 1-3.

Toinen Lindströmin suosikkisointu, jota hän käyttää erityisesti duurisävelmiensä huippukohdassa, on IVm-sointu (esimerkiksi C-duurissa sointu Fm). Mollimuotoinen subdominantti on populaarimusiikissa melko yleinen ja jopa kulunut ratkaisu, mutta koska Lindström käyttää sointua varsin säästeliäästi lähinnä kappaleidensa huippukohdissa, lopputulos kuulostaa tehokkaalta ja varsin yllättävältä, kuten sävelmässä Kuiskaa minulle (nuottiesimerkki 3).

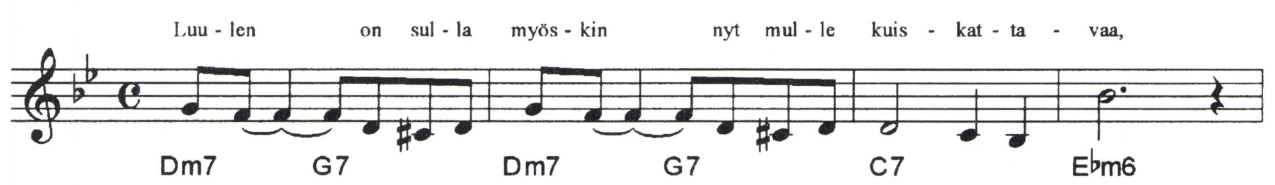

NUOTTIESIMERKKI 3. Kuiskaa minulle, tahdit 25-28.

Lindströmin tavaramerkkeihin kuuluvat myös moduloinnit hieman kaukaisempiin sävellajeihin. Yleensähän iskelmämusiikissa moduloidaan rinnakkaissävellajiin, sub- 
dominantille tai dominantille sekä - ehkäpä kaikkein kliseisimpänä ratkaisuna - kappaleen lopussa puoli sävelaskelta ylemmäksi. Lindström on kuitenkin muutamissa sävelmissään moduloinut hetkeksi esimerkiksi alennetulle III asteelle (C-duurista Esduuriin) tai alennetulle VI asteelle (esimerkiksi G-duurista Es-duuriin, kuten sävelmässä Yön värit, nuottiesimerkki 4).

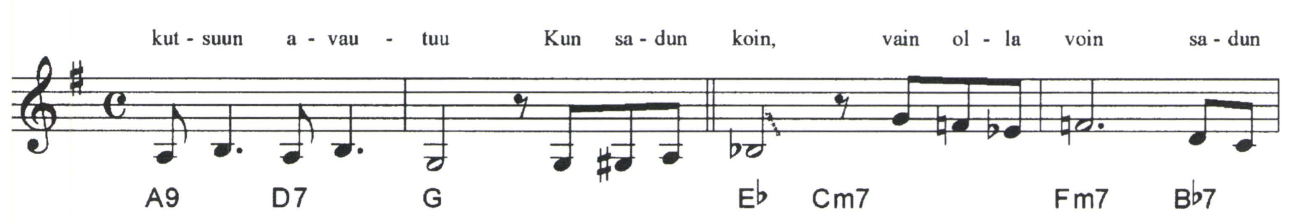

NUOTTIESIMERKKI 4. Yön värit, A- ja B-osan taite.

Vaikka edellä olenkin kuvannut Lindströmin perinteisen iskelmän soinnutusta laajentavia ratkaisuja, täytyy kuitenkin todeta, että varsin suuri osa hänen soinnutuksestaan perustuu sittenkin kaikkein tyypillisimpiin sointuihin eli sävellajin perussointuihin ja kvinttisuhteisiin sointusekvensseihin. Lindström (2002) ei ole omien sanojensa mukaan halunnut edetä iskelmissään liian kauas perinteisestä soinnutuksesta, jotta hän ei karkottaisi kuulijoita. Hän on kuitenkin ripotellut sointuihinsa sinne tänne muutamia persoonallista lisäväriä tuovia jazzmausteita. Hänen sävelmissään onkin varsin helposti tunnistettava ja suomalaista perusiskelmää jossain määrin kansainvälisempi sointi.

\section{Melodiat}

Erik Lindströmin melodiat ovat pääosin diatonisia eli niissä on käytetty sävellajin mukaisia säveliä. Kromaattisesti muunnettuja säveliä ei tutkimusaineiston kappaleissa juurikaan esiinny ainakaan rakenteellisesti tärkeinä nuotteina. Sen sijaan kromaattisia lomasäveliä kyllä esiintyy jossain määrin, mutta niillä ei yleensä ole suurempaa melodista painoarvoa. Mikäli kromaattisia säveliä on käytetty melodian tärkeinä sävelinä, kuten esimerkiksi sävellajin vähennetty kvintti sävelmässä Ranskalaiset korot (ks. nuottiesimerkki 9), niitä on tehostettu sopivasti valitulla soinnutuksella.

Erik Lindströmin melodiat liikkuvat kohtuullisen suppealla alalla, sillä melodian ambitus eli laajuus on keskimäärin 14,3 puolisävelaskelta eli noin suuren noonin luokkaa. Ambituksen keskihajonta on 2,2 puolisävelaskelta. Siten suurin osa tutkimusaineiston melodioiden ambituksista vaihtelee oktaavin ja suuren desimin (oktaavi + suuri terssi) välillä. Kaikkein suppein ambitus on sävelmässä Kielletty rakkaus, jossa melodia liikkuu ainoastaan suuren sekstin puitteissa (ks. nuottiesimerkki 1). Lindström on selvästi ottanut laulajan huomioon säveltäessään, sillä esimerkiksi suurin osa Martti 
Innaselle ja Juha Vainiolle sävelletyistä huumorilauluista liikkuu korkeintaan oktaavin alalla.

Kaikkein laajin ambitus on Letkajenkassa, jonka melodia liikkuu oktaavin ja pienen sekstin puitteissa. Kyseessä on rautalankayhtye The Adventurersille sävelletty instrumentaalikappale. Seuraavaksi laajimmat ambitukset ovat sävelmissä Enkö koskaan, Niin paljon kaunista on ja Maailmanpyörä, joiden ambitus on ylinouseva undesimi (oktaavi + ylinouseva kvartti). Näistä viimeksi mainittu on instrumentaalikappale.

Melodioiden kohtuullisen suppeista laajuuksista voidaan päätellä, että Erik Lindström on pyrkinyt helposti laulettaviin melodioihin, jotka eivät vaadi laulusolistilta kovinkaan laajaa äänialaa. Myös Lindströmin $(1993,2002)$ omat kommentit ovat samansuuntaisia. Melodioiden laulamisen helppoutta lisää vielä se, että ne ovat pääosin diatonisia.

Tutkimusaineistossa on paljon sellaisia melodiamotiiveja, jotka esiintyvät vain yhdessä tai muutamassa sävelmässä. Aineistosta nousee kuitenkin esiin tiettyjä motiiveja, jotka toistuvat selvästi useammin. Näiden motiivien rakenteellisesti tärkeät sävelet ovat useimmiten toonikakolmisoinnun säveliä (a-mollissa a, c ja e; C-duurissa c, e ja g).

\section{Mollimotiivit}

Selvästi yleisin mollisävelmien melodiamotiivi (lähes $30 \%$ kaikista mollimotiiveista) perustuu sävellajin kvinttiin (a-mollissa sävel e), joka on sijoitettu tahdin ensimmäiselle iskulle. Kvinttiä seuraa useimmiten laskeva sävelkulku. Peräti kolmasosassa kvintillä alkavista motiiveista melodia laskee saman tien takaisin perussäveleen, joko suoraan alaspäisellä kvinttihypyllä (a-mollissa hyppy e-a) tai yhden tai useamman välisävelen kautta. Välisävelenä toimii tällöin yleisimmin terssi, jolloin melodiassa on siis laskeva mollikolmisointu (e-c-a). Melodia saattaa laskea perussävelen sijaan myös esimerkiksi terssille tai sekunnille. Toisinaan melodia jää myös pyörimään kvintin ympärille. Sen sijaan kvinttiä seuraava nouseva melodialinja on harvinaisempi.

Lindströmin suosima motiivi muistuttaa Unto Monosen ns. Satumaa-kuvion riisuttua muotoa. Täydellisessä Satumaa-kuviossa yläkvintistä edetään perussäveleen ja siitä alakvintin kautta yläkvinttiin (Sjöblom 1994: 73-74). Riisutusta muodosta puuttuu nouseva sävelkulku alakvintiltä yläkvinttiin. Sjöblomin tutkimuksessa täydellinen Satumaa-kuvio löytyi $20 \%$ ja riisuttu muoto $13 \%$ analysoiduista 15 Monosen sävelmästä.

Antti Karhumäen (1999: 31) tutkimuksen mukaan laskeva kvintti löytyi peräti 40 \% kotimaisista huippuhiteistä, ja $12 \%$ sävelmistä se muodosti "laulun ytimen". Pekka Jalkasen (1993) mukaan suomalaisen iskelmämusiikin laskevan kvintin juuret ovat kalevalaisessa kvinttipentakordissa ja protestanttisessa virsilaulussa. 
Tangoparodia Elsa, kohtalon lapsi (nuottiesimerkki 5) on hyvä esimerkki alaspäisestä kvinttihypystä. Lisäksi nuottiesimerkin toisessa tahdissa on Lindströmille tyypillinen alapuolinen kromaattinen sivusävel ja kolmannessa tahdissa melodiasävelen kvarttipidätys.

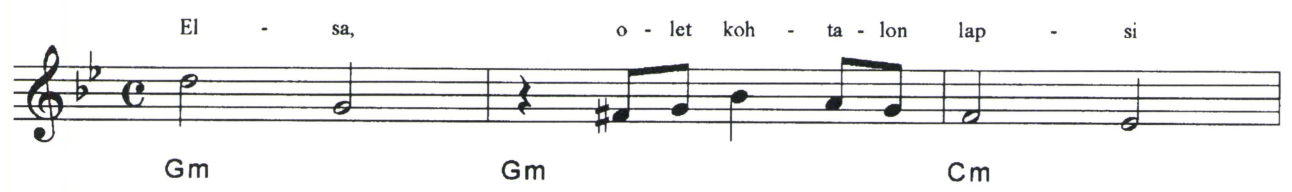

NUOTTIESIMERKKI 5. Elsa, kohtalon lapsi, tahdit 1-3.

Seuraavaksi yleisin Lindströmin mollisävelmien melodiamotiivi perustuu sävellajin toonikasäveleen (a-mollissä sävel a). Tämä sävel on useimmiten soinnutettu sävellajin IV asteen soinnulla (a-mollissa soinnut Dm ja Dm7). Motiivia käytetään erittäin usein AABA-muotoisten kappaleiden B-osan alussa, kun moduloidaan rinnakkaisduuriin. Tutkimusaineiston kaikista mollimotiiveista toonikasäveleen perustuvia motiiveja on lähes $20 \%$.

Toonikasäveltä edeltää toisinaan ylöspäinen oktaavihyppy. Tämä on yksi Toivo Kärjen suosimista melodisista tehokeinoista, jota hän käyttää usein aivan samassa tarkoituksessa kuin Lindström eli moduloitaessa rinnakkaisduuriin (ks. Henriksson \& Kukkonen 2001: 121-125). Lindströmin sävellyksissä motiivi esiintyy siis myös riisutussa muodossa, jossa melodiassa ei ole oktaavihyppyä. Varsin yleistä on IV asteen soinnun vähennetyn kvintin (tai ylinousevan kvartin) käyttö kromaattisena sivusävelenä. Sävelmässä Turistit Tuppukylään (nuottiesimerkki 6) on sekä melodian oktaavihyppy että kromaattinen sivusävel.

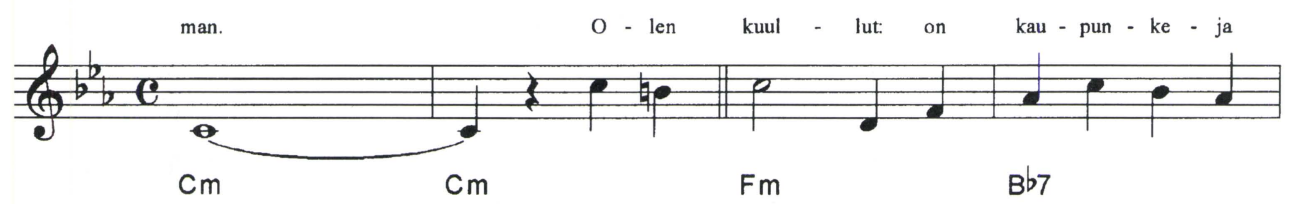

NUOTTIESIMERKKI 6. Turistit Tuppukylään, A- ja B-osan taite.

Nousevalla pienellä sekstillä sävellajin kvintistä terssiin (a-mollissa e-c) hyppäävä melodiakulku on suomalaissa iskelmässä erittäin yleinen melodiamotiivi. Sekstihyppyä seuraa yleensä alaspäinen melodialinja. Kutsun jatkossa mollisekstimotiiviksi melodiakulkua, jonka muodostavat ylöspäinen pieni seksti ja sitä seuraava laskeva melodialinja.

Esimerkiksi Risto Kukkosen tutkimusten mukaan mollisekstimotiivi löytyy peräti joka toisesta Toivo Kärjen hittikappaleesta (Henriksson \& Kukkonen 2001: 101-112). 
Jouni Sjöblom (1994: 74) on puolestaan löytänyt ylöspäisen sekstihypyn joka kolmannesta tutkimastaan Unto Monosen sävellyksestä. Antti Karhumäen (1999: 32) tutkimuksessa mollisekstihyppy löytyi kaikkiaan joka neljännestä analysoidusta kotimaisesta huippuhitistä.

Erik Lindströmin sävelmistä noin $15 \%$ sisälsi sävellajin terssiin perustuvia melodiamotiiveja. Useimmiten melodiasta kuitenkin puuttuu sekstihyppy. Melodia alkaa joko suoraan terssiltä, tai sille edetään joltain muulta säveleltä kuin alakvintiltä, esimerkiksi toonikasäveleltä (a-mollissa hyppy a-c). Puhdas mollisekstimotiivi löytyy ainoastaan kolmesta tutkimusaineiston sävelmästä.

Yksi niistä harvoista sävelmistä, joissa Lindström käyttää mollisekstimotiivia, on tangoparodia Esteri, tyttö sadepisarain. Kappale parodioi suomalaista perustangoa esimerkiksi korostetun "hakkaavalla" säestyksellä (ks. Koivusalo 1994; Henriksson \& Kukkonen 2001: 60-63). Myös mollisekstimotiivin käyttö tuo kappaleeseen perinteisen suomalaisen iskelmän tunnelmaa.

Lindström on sijoittanut sävelmän kolmanteen tahtiin mielenkiintoisen melodisharmonisen koukun. Melodiassa on dis-sävel, joka voidaan tulkita enharmonisesti essäveleksi, joka puolestaan on a-mollin vähennetty kvintti eli ns. blue note -sävel (nuottiesimerkki 7; ks. tarkemmin Henriksson 2002).

Kun analysoidaan vähänkään monimutkaisempia melodis-harmonisia ilmiöitä, on usein löydettävissä useita teoreettisesti perusteltavissa olevia tulkintoja. Tässäkin tapauksessa dis-sävel voidaan tulkita myös a-mollin ylinousevaksi kvartiksi, jolloin se viittaa melodisesti esimerkiksi mustalaismolliin. Sävelen tulkitsemista ylinousevaksi kvartiksi tukee myös se, että se on harmonisoitu mollin II asteen dominanttiseptimisoinnulla (a-mollissa H7). Tätä sointua ei kuitenkaan pureta tavalliseen tapaan V7sointuun (E7), vaan sävellajin IV asteelle (Dm). Koska sointu on kahden melodiafraasin rajalla, ei sen "oikeaoppinen" purkaminen ole välttämätöntä. Erik Lindströmin sävelkieleen purkamatta jäävät dominanttiseptimisoinnut eivät kuitenkaan yleensä kuulu edes melodiafraasien rajoilla.

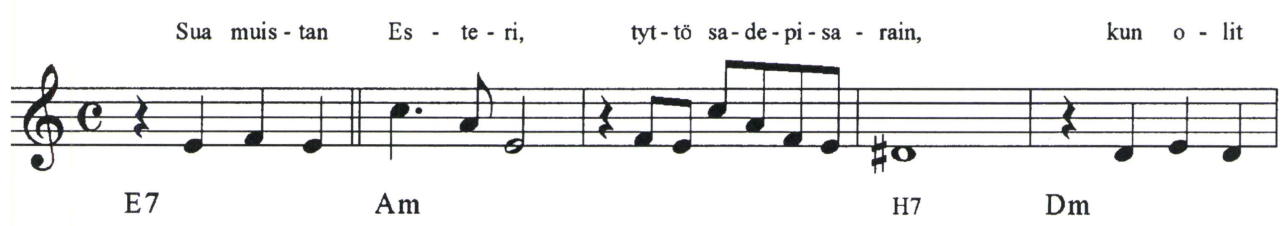

NUOTTIESIMERKKI 7. Esteri, tyttö sadepisarain, tahdit 1-3.

Eräänlaisena mollisekstimotiivin vajaamuotona voidaan pitää myös tutkimusaineiston muutamassa sävelmässä esiintyvää motiivia, jossa kvintiltä hypätään suoraan noonille (a-mollissa hyppy e-h). Mollisekstimotiivista on siis jätetty molliterssi pois, jolloin motiivi ei alakaan nousevalla mollisekstillä vaan kvintillä, kuten sävelmässä Pois 
haihtuu haaveet (nuottiesimerkki 8). Tällöin motiivi ei kuulosta yhtä kliseiseltä kuin puhdas mollisekstimotiivi, mutta melodiassa olevaa noonia voidaan silti käyttää tehokkaana pidätyssävelenä.

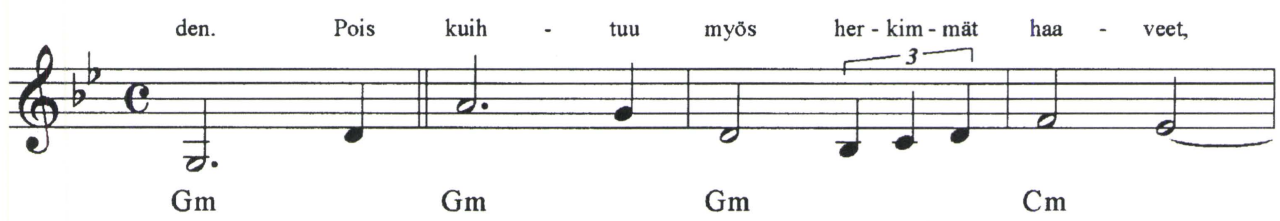

NUOTTIESIMERKKI 8. Pois haihtuu haaveet, versen ja choruksen taite.

Edellä kuvattujen motiivien lisäksi mollisävelmistä löytyi myös muita melodiamotiiveja, jotka esiintyvät vain yhdessä tai muutamassa sävelmässä. Esimerkiksi Ranskalaisten korkojen hyvin karaktäärinen melodiamotiivi perustuu sävellajin kromaattisesti muunnettuun kvinttiin, joka on soinnutettu bVI7-soinnulla (a-mollissa sävel es, joka on harmonisoitu F7-soinnulla). Tämä ns. blue note -sävel tuo kappaleeseen bluesmaisen tunnelman (nuottiesimerkki 9, ks. tarkemmin Henriksson 2002).

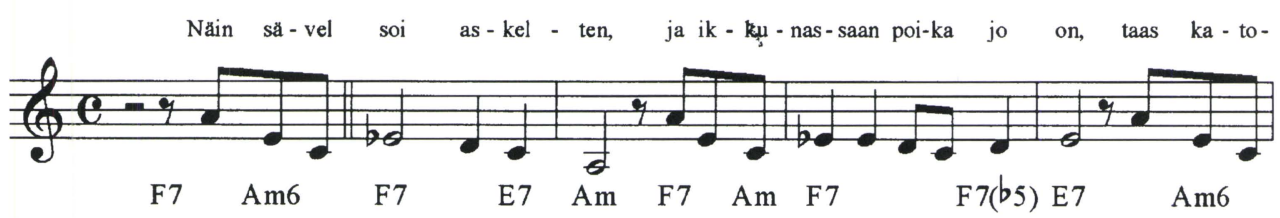

NUOTTIESIMERKKI 9. Ranskalaiset korot, tahdit 1-4.

\section{Duurimotiivit}

Lindström ei siis juurikaan käytä nousevaan mollisekstiin perustuvia motiiveja. Sen sijaan vastaavan motiivin duuriversio on Lindströmin kaikkein eniten käyttämä duurisävelmien melodiamotiivi. Näitä duurisekstimotiiveja oli duurikappaleiden motiiveista noin 25 \%. Sävellajin kvintiltä edetään sekstihypyllä terssille (esim. C-duurissa hyppy g-e), josta laskeudutaan yleensä asteittain alaspäin. Laskevaan liikkeeseen sisältyy toisinaan noonipidätyksiä $(\mathrm{d}-\mathrm{c})$. Nouseva sekstihyppy ei välttämättä esiinny puhtaana, vaan sitä on saatettu täyttää esimerkiksi murtosoinnulla tai astekululla, kuten sävelmässä Lady Dee (nuottiesimerkki 10). Sävelmän kolmannessa tahdissa on myös yksi kaikkein tehokkaimmista Lindströmin käyttämistä pidätyssävelistä - ylinouseva kvartti. 


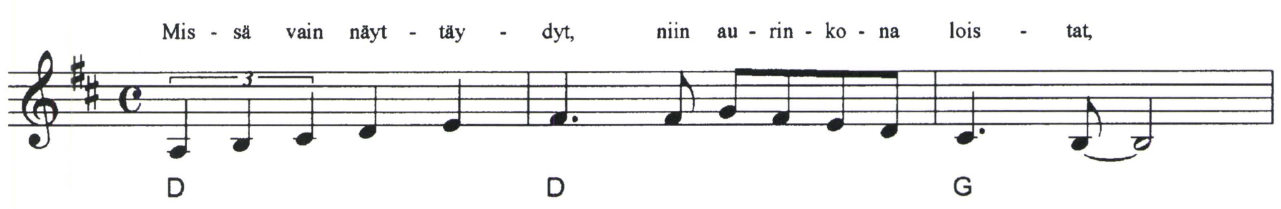

NUOTTIESIMERKKI 10. Lady Dee, tahdit 1-3.

Tutkimusaineistossa esiintyy myös duurisekstimotiivin "käännettyä” versiota, jolloin melodia alkaa kvintiltä, josta laskeudutaan pieni terssi alaspäin sävellajin terssille. Näitä motiiveja oli noin puolet vähemmän kuin alakvintiltä yläterssille nousevia motiiveja. Muutamassa motiivissa kvintiltä terssille laskevaa liikettä jatketaan, mutta useimmiten laskeva pieni terssi tasapainotetaan nousevalla liikkeellä.

Duurisekstimotiivin lisäksi duurimelodioissa esiintyy toki myös lukuisia muita, harvinaisempia motiiveja. Varsin monessa sävelmässä on käytetty tietyn sävelen toistoon perustuvia motiiveja. Osa duurimelodioista - aivan kuten monet mollimelodiatkin - on selkeästi rakennettu harmonian ehdoilla eli niiden keskeisinä elementteinä ovat joko pidätyssävelet tai harmoniaa alleviivaavat kromaattiset muunnesävelet. Kaikkiaan noin $15 \%$ duurimotiiveista perustuu toonikan noonin, septimin tai sekstin pidätyksiin (C-duurissa pidätykset d-c, h-a ja a-g). Soinnutusta alleviivaavia kromaattisia melodioita on käytetty esimerkiksi kromaattisesti laskevien mollisointukulkujen (esimerkiksi Em7-Ebm7-Dm7) yhteydessä tai niissä sävelmissä, joissa moduloidaan hetkeksi kaukaisempiin sävellajeihin, kuten duurin alennetulle kuudennelle asteelle (esimerkiksi G-duurista Es-duurin, ks. nuottiesimerkki 4).

\section{Persoonallista ja perinteistä}

Erik Lindströmin melodiat ovat siis pääosin diatonisia ja ambitukseltaan useimmiten varsin suppeita. Melodian runkosävelet ovat useimmiten toonikasoinnun säveliä. Lindström on aivan selvästi pyrkinyt melodioiden helppoon laulettavuuteen. Tärkeimmät melodiamotiivit ovat etupäässä samoja, joita suomalaisessa iskelmässä muutenkin käytetään. Poikkeuksen muodostaa suomalaisessa populaarimusiikissa hyvin suosittu pienellä sekstillä alkava motiivi, jota esimerkiksi Toivo Kärki käyttää erittäin paljon. Tuntuu siltä, että Lindström olisi jopa tietoisesti vältellyt tätä suomalaisen kevyen musiikin kliseetä sävelmissään.

Vaikka Lindströmin melodiat ovat useimmiten varsin perinteisiä, hänen sävelmissään on siitä huolimatta astetta suomalaista perusiskelmää kansainvälisempi sointi. Yhtenä syynä on se, että hän on soinnuttanut melodiansa siten, että melodiasävelet muodostavat tehokkaita sointuja laajentavia pidätyksiä. Tässä suhteessa hän muistuttaa Toivo Kärkeä. Lindström käyttää kuitenkin enemmän kromaattisia muunnesäveliä soinnutuksessaan kuin Kärki tai useimmat muut suomalaiset iskelmäsäveltäjät. 
Lisäksi Lindström on säveltänyt enemmän hitaita duurifokseja ja "lattareita" kuin suomalaiset iskelmäsäveltäjät keskimäärin.

Lindström (1993) on itse todennut, että hänen mielestään säveltäminen on "palveluammatti". Hän ei ole omien sanojensa mukaan aina "uskaltanut" säveltää juuri siten, kuin olisi itse halunnut, vaan on joutunut tyytymään kompromisseihin tavoittaakseen iskelmilleen suuremman yleisön. Omasta mielestäni Lindström onkin saavuttanut iskelmissään varsin onnistuneen tasapainon perinteisten ja persoonallisten elementtien välillä.

\section{Lähteet}

\section{KIRJALLISET LÄHTEET}

Henriksson, Juha (1998) Chasing the Bird. Functional Harmony in Charlie Parker's Bebop Themes. Acta Musicologica Fennica 21. Helsinki: Suomen Musiikkitieteellinen Seura. Henriksson, Juha (2002) "Erik Lindströmin siniset sävelet". Musiikin suunta 2/2002, ss. 411.

Henriksson, Juha \& Risto Kukkonen (2001) Toivo Kärjen musiikillinen tyyli. Helsinki. Suomen Jazz \& Pop Arkisto.

Jalkanen, Pekka (1993) "Suomalaisen iskelmän tyylit". Musiikin suunta 3/1993, ss. 48-54.

Karhumäki, Antti (1999) Kotimaisen huippuhitin muotokuva. Suomen tunnetuimpien iskelmien musiikilliset yhtäläisyydet. Julkaisematon pro gradu -tutkielma. Tampereen yliopisto, kansanperinteen laitos.

Koivusalo, Eija (1994) "Tangon musiikillisia vaiheita Suomessa". Musiikin suunta 3/1994, ss. $27-40$.

Kukkonen, Risto (2001) Melodiamotiivien muuntelu Toivo Kärjen iskelmissä. Paradigmaattinen melodia-analyysi. Julkaisematon pro gradu -tutkielma. Helsingin yliopisto, taiteiden tutkimuksen laitos, musiikkitieteen oppiaine.

Kuljuntausta, Petri (1994) "Paradigmaattisen analyysin mahdollisuudet. Eric Dolphyn jazzimprovisaatioiden analyysi." Etnomusikologian vuosikirja 6/1994. Toim. Erkki Pekkilä. Helsinki: Suomen etnomusikologinen seura. Ss. 204-238.

Motte, Diether de la (1976) Harmonielehre. Kassel: Bährenreiter-Verlag \& München: Detscher Taschenbuch Verlag.

Nattiez, Jean-Jacques (1982) "Taksonomisesta analyysista tyylin kuvaukseen: Debussyn Syrinx." Kääntänyt Eero Tarasti. Musiikin soivat muodot. Musiikintutkimuksen teorioita ja menetelmiä. Toim. Eero Tarasti. Jyväskylä: Jyväskylän yliopiston musiikkitieteen laitos. Ss. 95-126.

Nurmesjärvi, Terhi (2000) "Aloitetaan kertosäkeistöllä". Musiikin suunta 2/2000, ss. 4256.

Pekkilä, Erkki (1988) Musiikki tekstinä. Kuulonvaraisen musiikkikulttuurin analyysiteoriaja metodi. Acta Musicologica Fennica 17. Helsinki: Suomen Musiikkitieteellinen Seura.

Sjöblom, Jouni (1994) Kohtalon tango. Unto Monosen elämän ja teosten yhteys. Julkaisematon pro gradu -tutkielma. Tampereen yliopisto, kansanperinteen laitos. 


\section{HAASTATTELUT}

Lindström, Erik (1993) Haastattelut tv-dokumentissa Suomalaisen populaarimusiikin vaikuttajia. Erik Lindström - Jazzia ja svengiä. Haastattelija Pekka Jalkanen. Helsinki: LUSES \& FIMIC \& TEOSTO.

Lindström, Erik (2002) Haastattelu 9.9.2002. Haastattelija Juha Henriksson.

\section{TUTKIMUSAINEISTON SÄVELMÄT}

Nimi

Ajatuksia yössä

Armi

Askelees kuulu ei

Elsa, kohtalon lapsi

Enkö koskaan

Entisajan joulukuu

Esteri, tyttö sadepisarain

Florida

Gunnar vierasmaalainen

Hattara

Hellästi

Helsingin laulu

Herrat Helsingin

Hiljaista on

Iloinen sävel

Jamit

Juhannustanssit

Kahden bossa nova

Kelle kuulut

Kevättunnelmaa

Kielletty rakkaus

Kuiskaa minulle

Kumiteräsaappaat

Kun yksin on

Kuu peilissä

Kuunsilta

Kylmä rakkaus

Lady Dee

Lehtimummo

Letkajenkka

Liian vähän aikaa

Maailmanpyörä

Madame La Plume

Manhattan tango

Mesenaatti Montonen

Miksi kerroit mulle valheen

Missä neljä tuulta kohtaa

Morsiusvalssi

Muistatko Monrepos'n

Niin paljon kaunista on

Niin tai näin

On suru jäänyt sydämeen

On yö
Vuosi Tyylilaji

1991 slow fox

1952 foxtrot

1960 slow fox

1967 tango

1963 tango

1976 moderato

1967 tango

1973 humppa

1967 foxtrot

1990 bossa nova

1986 slow fox

1954 foxtrot

1966 samba

1968 foxtrot

1954 foxtrot

1965 foxtrot

1965 foxtrot

1962 bossa nova

1963 beguine

1957 valssi

1963 bolerobeguine

1958 slow fox

1968 humppafoxtrot

1960 beguine

1961 slowly

1957 tango

1954 beguine

1990 slow beat

1963 valssi

1963 rautalanka

1959 foxtrot

1977 valse musette

1963 slow fox

1974 tango

1979 foxtrot

1960 tango

1959 slow fox

1977 valssi

1955 valssi

1986 slow beat

1974 moderato beat

1980 beat beguine

1957 tango 


\begin{tabular}{lll} 
Pikku midinetti & 1958 & valssi \\
Pois haihtuu haaveet & 1991 & slow beat \\
Poliisi & 1966 & foxtrot \\
Portinvartija & 1961 & valse musette \\
Ranskalaiset korot & 1959 & slow fox \\
Ruska-aika & 1964 & balladi \\
Sano morjens vaan & 1972 & polkka \\
Satamassa yö & 1959 & beguine \\
Senhän sanoo järkikin & 1975 & pop beat \\
Soi yössä hiljaa bandoneon & 1991 & tango \\
Suolaa, suolaa & 1965 & shake \\
Suurinta on rakkaus & 1991 & foxtrot \\
Syksyn laulu & 1957 & beguine \\
Tahdon saaren & 1965 & shake \\
Tango Romano & 1964 & tango \\
Toinen oikealta & 1959 & foxtrot \\
Totta toinen puoli & 1962 & slow fox \\
Tunnetko rytmin & 1992 & foxtrot \\
Turistit Tuppukylään & 1965 & foxtrot \\
Tuuli tuo, tuuli vie & 1956 & foxtrot \\
Tää tie & 1990 & tango \\
Tään saako aikaan kenties toinen & 1980 & slow beat \\
Uinahtaen & 1990 & slow fox \\
Urjalan taikayö & 1967 & jenkka \\
Vain aika parantaa & 1962 & beguine \\
Vanhan pianon tarina & 1962 & slow fox \\
Vilkkuvat majakat & 1974 & slow beat \\
Virran viemää & 1959 & valssi \\
Yön värit & 1959 & slow beat \\
Yötön yö & 1980 & disco beat \\
& & \\
\hline
\end{tabular}

\section{MUUT VERTAILUAINEISTON SÄVELMÄT}

Aavehiihtäjä; Aavoja päin; Ahvenanmeri; Avoin ovi; Ei enää kyyneleitä; En halua uutta maailmaa; Elämän kortti; En paljon saanut; Hei, eteenpäin!; Heitä reilusti pois minut mielestäs; Hellitetään hetkeksi; Hiljainen tango; Hän tulee; Härmän chanson; I remember Janatuinen; Ilta vain; Isoäidin joululahja; Joulupukin kehtolaulu; Jos muistat; Jurba leddu; Jämsän äijä; Jääpalacalypso; Kaamos; Kaikki järjestyy; Kaipuu juurilleen; Kaivolla kahden; Kaksi onnellista päivää; Kellot; Kohtalo; Koiravaljakko; Korven kuuset; Kuin tumma yö; Kukkuva kitara; Kultahäävalssi; Kultainen medaljonki; Kultaiset vuodet; Kumpaa tietä kuljet; Kun lintu kotiin löytää; Kun lähellä on ystäväin; Kun sävel siivet saa; Kuutamossa; Kyynelsilmät; Laina-aurinko; Lapsuuteni joki; Lehtolapsi; Lentäen sun luo; Lunta sataa; Luulit minun pettävän; Mies joka unohtaa menneen; Miesten polkka; Miksi sen teit?; Muisto eilinen; Mun täytyy uneksia vain; Naapuri; Niin paljon kertomatta ois; Norsunluiset nopat; Näen maailman uusin silmin; Onnellinen oloneuvos; On kaunis synnyinmaa; Ookkonä Oulusta?; Pietarin iloja; Pikku tyttöni; Pisto; Pohjanmaan tango; Pois; Pom-pom; Päivä kerrallaan; Rakastan; Reissumiehet; Rekka-humppa; Romaniruusu; Saan kesän uudelleen; Saavun taas; Saint Tropez; Sambaionova; Sano, rakastathan mua; Se muistokseni jää; Suru; Surusunnuntai; Sylissäsi sun; Sä oot ainoa mulle; Takuulla, sano Tampereen tyttö; Tango kannella; Tango tunturissa; Tangokuningas; Tuhlaat rakkautesi minuun; Tule elämäni syksyyn; Tuuli tietää; Tää on vain elämää; Vain ei on sanas sun; Valheita; Valot sammuu; Vanhan penkin tarina; Vanhat hirret; Viimeinen suudelma; The wind; Yksi vain. 